\title{
PENGEMBANGAN LAYANAN INFORMASI KARIER BERBASIS MEDIA BLOG UNTUK MENINGKATKAN EKSPLORASI KARIER SISWA DI SMP KOTA MAGELANG
}

\author{
Ari Murdiyanto $^{1)}$, Edi Purwanta ${ }^{2)}$, Kamaruddin $^{3)}$ \\ 1) Program Studi Bimbingan dan Konseling Universitas Negeri Yogyakarta, Yogyakarta, Indonesia \\ Email:ijoroyo90@gmail.com \\ ${ }^{2)}$ Fakultas Ilmu Pendidikan Universitas Negeri Yogyakarta, Yogyakarta, Indonesia \\ Email:edi_plb@yahoo.co.id \\ ${ }^{3)}$ Program Studi Bimbingan dan Konseling STKIP Singkawang, Singkawang, Indonesia \\ Email:kamaruddinoke@yahoo.com
}

\begin{abstract}
Abstrak. Penelitian pengembangan ini bertujuan: (1) menghasilkan informasi karier berbasis media blog yang layak sebagai layanan untuk digunakan siswa di SMP Kota Magelang, dan (2) mengetahui efektifitas layanan informasi karier berbasis media blog untuk meningkatkan eksplorasi karier siswa di SMP Kota Magelang.Pendekatan yang digunakan adalah penelitian dan pengembangan (Research and Development). Prosedur pengembangan penelitian mengacu pada prosedur Borg \& Gall. Teknik sampel menggunakan Cluster Random Sampling. Subjek penelitian yaitu, 28 siswa kelas VIII G di SMP Negeri 8 Magelang dan 21 siswa kelas VIII A di SMP Muhammadiyah Magelang. Instrument pengumpulan data menggunakan lembar evaluasi uji ahli materi; lembar evaluasi uji ahli media, kelompok kecil, dan kelompok besar; serta skala eksplorasi karier. Analisis data uji coba skala eksplorasi karier dengan taraf signifikan $5 \%$ dengan subjek uji 31 responden diketahui logical validity 0.355 dan reliabilitas 0.960 . Hasil penelitian menunjukkan bahwa (1) informasi karier berbasis media blog layak menjadi layanan untuk digunakan siswa di SMP Kota Magelang dan (2) layanan informasi karier berbasis media blog layak untuk meningkatkan eksplorasi karier siswa SMP di Kota Magelang. Berdasarkan hasil uji normalitas pre test dan post test, nilai probabilitas pre test dan post test lebih besar dari taraf signifikan 5\% (pre test $0.297>0.05$ dan post test $0.361>$ 0.05) maka data dikatakan berdistribusi normal, sedangkan hasil uji t diketahui taraf signifikan pre test dan post test lebih kecil dari taraf signifikan $5 \%(0.000 \leq 0.05)$.
\end{abstract}

Kata Kunci: Layanan Informasi Karier Berbasis Media Blog; Eksplorasi Karier

\section{Pendahuluan}

Siswa Sekolah Menengah Pertama (SMP) berusia sekitar 12 sampai 15 tahun yang sangat membutuhkan layanan bimbingan karier. Murro, Kottman, \& Arington (dalam [1]), menyatakan fase eksplorasi karier terjadi mulai pada usia SMP. Siswa mengalami masa transisi menuju eksplorasi karier yang belum mampu untuk menentukan program studi keahlian dan kelanjutan studinya. Super (dalam [2]), menyatakan anak berusia 12 sampai 14 tahun harus mampu mengembangkan kapasitas atau kemampuan dan berada pada masa transisi menuju eksplorasi. Eksplorasi karier mencakup kegiatan pengumpulan informasi dan pengetahuan tentang pencarian pekerjaan, perencanaan, peluang, dan pilihan karier.
Salah satu layanan bimbingan karier dari guru Bimbingan dan Konseling untuk memberikan pemahaman eksplorasi karier siswa dalam menentukan program studi keahlian dan kelanjutan studi yaitu pemberian layanan informasi karier. O’Donogue [3], menyatakan informasi karier menyediakan informasi tentang berbagai pilihan dalam pendidikan, pelatihan dan pekerjaan, serta pengembangan peluang dengan orang pilihan. Norris, Zeran, \& Hatch (dalam [4]), menyatakan yang memungkinkan siswa mempergunakan berbagai cara untuk memperdalam dan memperluas pemahaman dunia kerja pada umumnya dan bidang pekerjaan tertentu pada khususnya, mengembangkan rencana pekerjaan sementara yang akan dipegang setamat sekolah, dan memiliki pengetahuan atau mempunyai hubungan dengan pekerjaan tertentu apabila peserta didik memang menghendaki untuk memegang jabatan atau 
sementara setamat sekolah. Layanan informasi karier selain digunakan untuk memberikan pemahaman eksplorasi karier siswa dalam menentukan program studi keahlian dan kelanjutan studi juga mempunyai peran membantu mengembangkan rencana pekerjaan sementara yang akan dijabat.

Berdasarkan hasil wawancara pada 16 September 2015, diketahui beberapa siswa di SMP Kota Magelang mempunyai masalah eksplorasi karier dalam menentukan program studi keahlian dan kelanjutan studi. Beberapa koordinator dan guru Bimbingan dan Konseling di SMP Kota Magelang menyatakan bahwa siswa mempunyai masalah dalam menentukan program studi dan kelanjutan studi. Layanan informasi karier diberikan menggunakan metode ceramah dan menggunakan media brosur dari panitia PPDB di SMA dan SMK Kota Magelang. Siswa menganggap hanya sekolah favorit dan informasi SMA dan SMK dari brosur yang dijadikan tujuan utama kelanjutan studi.

Beberapa guru Bimbingan dan Konseling yang terlibat dalam panitia PPDB pada salah satu SMA di Kota Magelang menyatakan beberapa siswa pendaftar menentukan program jurusan keahlian karena keunggulan atau prestasi, ajakan teman, dan saran orang tua. Guru Bimbingan dan Konseling pada salah satu SMK di Kota Magelang menyatakan beberapa siswa pendaftar menentukan program studi keahlian hanya melihat pada peluang kerja lulusan. Guru Bimbingan dan Konseling di SMA dan SMK Kota Magelang yang terlibat PPDB harus memberikan pengarahan kepada siswa pendaftar atau calon siswa SMA dan SMK untuk membantu menentukan program studi keahlian sesuai minat dan bakat. Berdasarkan hasil wawancara diketahui siswa mempunyai permasalahan eksplorasi karier dalam menentukan program studi keahlian dan kelanjutan studi.

Informasi karier dapat disampaikan melalui media cetak maupun elektronik untuk memberikan pemahaman eksplorasi karier. Penelitian menggunakan media cetak terkait eksplorasi karier pernah diteliti Anwar [5] dengan mengembangkan buku kerja eksplorasi karier. Hasil penelitian menyatakan buku kerja eksplorasi karier dapat membantu siswa untuk menggali minat, nilai suatu pekerjaan, potensi, dan mengenali beberapa jenis pekerjaan.Saran peneliti yaitu penelitian selanjutnya dapat memanfaatkan media elektronik untuk membantu siswa SMP dalam mengeksplorasi kariernya. Menurut Norris, perpustakaan merupakan tempat menyimpan sebagian informasi dalam layanan informasi karier. Menurut McCarty, mengamati pemberian layanan informasi pendidikan awal, pemberian informasi perguruan tinggi, dan pustakawan menyebarkan informasi melalui jaringan internet untuk mendukung pelaksanaan bimbingan [6].

Holland (dalam [7]), menyatakan layanan informasi menggunakan teknik berbasis komputer baik CD-ROM atau berbasis jaringan internet dapat membantu dalam eksplorasi dan pengambilan keputusan karier. The Scottish Government [8], menyatakan banyak orang beralih menggunakan jaringan internet untuk memberikan informasi melalui jejaring sosial, web chat, dan konten video online.

Penelitian memanfaatkan media komputer dan internet terkait eksplorasi pernah diteliti Daniel [9]. Hasil penelitian menyatakan terdapat perilaku menyimpang dalam penggunakan media komputer dan internetdengan mengunjungi situs pornografi, mengakses website orang tanpa ijin, dan tindakan menyimpang lainnya. Saran peneliti supaya guru Bimbingan dan Konseling serta orang tua dapat mencegah perilaku menyimpang pada siswa SMP dan SMA/ SMK ketika menggunakan media komputer dan internet ketika mengeksplorasi kariernya.

Dampak pemanfaatan media internet terkait eksplorasi karier pernah diteliti Miller [10]. Hasil penelitian menyatakan pemanfaatan media internet berdampak positif untuk siswa yang mempunyai masalah gangguan emosi untuk menemukan, mempersiapkan, dan mengkomunikasikan minat karier terhadap eksplorasi karier. Saran peneliti supaya penelitian selanjutnya harus mengembangkan informasi supaya siswa lebih memahami eksplorasi kariernya.

Peneliti mengembangkan informasi karier yang dikemas mengggunakan media website jenis blog untuk memberikan layanan untuk meningkatkan eksplorasi karier siswa di SMP Kota Magelang. Dearstyne (dalam [11]), menyatakan salah satu cara penyampaian materi pendidikan yaitu melalui weblog dengan jaringan publik maupun swasta. Weblog menyediakan sarana untuk mengumpulkan, mengorganisasi wawasan dan opini baru, serta sebagai media untuk meningkatkan produktivitas informasi.

Informasi karier berbasis media blog yang dikembangkan peneliti dengan memberikan informasi tentang persyaratan administrasi, persyaratan fisik, program studi keahlian, kapasitas pendaftar, keunggulan atau prestasi program studi keahlian, kegiatan dan prestasi ekstra kurikuler, serta peluang kerja lulusan. Informasi karier berbasis media blog menyertakan skala peminatan dengan program Adobe Flash supaya siswa memahami minat, bakat, dan kemampuan akademik atau kejuruan sebelum menentukan program studi keahlian dan kelanjutan studi. Pengertian peminatan dijelaskan dalam Peraturan Menteri Pendidikan dan Kebudayaan [12] tentang Bimbingan dan Konseling pada Pendidikan Dasar dan Pendidikan Menengah. Tujuan peminatan dijelaskan dalam [13] tentang Peminatan pada Pendidikan Menengah.

Terdapat dua pertanyaan dalam penelitian ini, yaitu: Apakah informasi karier berbasis media blog layak menjadi layanan untuk digunakan siswa SMP di Kota Magelang? Apakah layanan informasi karier berbasis media blog efektif untuk meningkatkan eksplorasi karier siswa di SMP Kota Magelang? Kedua pertanyaan tersebut yang harus dijawab dalam hasil penelitian. 


\section{METODE}

Pengembangan informasi karier berbasis media blog didasarkan model research and development $(\mathrm{R} \& \mathrm{D})$ Borg \& Gall. Borg \& Gall [14], mengemukakan bahwa terdapat sepuluh tahap dalam penelitian pengembangan. Pengembangan informasi karier berbasis media blog menerapkan delapan tahapan, yaitu pengumpulan informasi, perencanaan, uji pengembangan produk awal, uji kelompok kecil, revisi pengembangan produk utama, uji kelompok besar, revisi pengembangan produk utama, dan penerapan.

Penelitian dilaksanakan di SMP Kota Magelang dan penentuan sampel menggunakan Cluster Random Sampling. Populasi sebanyak 25 SMP di Kota Magelang.Sampel dengan taraf kesalahan 5\%, maka sampel yang diambil sebanyak 2 SMP yaitu SMP Negeri 8 Magelang dan SMP Muhammadiyah Magelang.

Tingkat eksplorasi karier diukur menggunakan skala eksplorasi karier. Skala eksplorasi karier divalidasi ahli kemudian diujicobakan kepada 31 siswa. Uji coba produk kepada ahli media dan materi, praktisi, kelompok kecil, serta kelompok besar menggunakan lembar evaluasi. Uji efektifitas informasi karier kepada 28 siswa di SMP Negeri 8 Magelang dan 21 siswa di SMP Muhammadiyah Magelang dengan total 49 siswa. Pada uji efektifitas dilaksanakan pre test, penerapan layanan informasi karier berbasis media blog, dan post test. Untuk mengetahui efektifitas layanan informasi karier berbasis media blog dilakukan uji normalitas dan uji t. Uji normalitas diolah menggunakan SPSS dengan ShapiroWilk dikarenakan jumlah sampel kurang dari 50.

\section{HASIL DAN PEMBAHASAN}

Pengembangan informasi karier berbasis media blog didasarkan model research and development (R\&D) Borg \& Gall. Delapan tahap yang sudah dilaksanakan yaitu pengumpulan informasi, perencanaan, uji pengembangan produk awal, uji kelompok kecil, revisi pengembangan produk utama, uji kelompok besar, revisi pengembangan produk utama, dan penerapan. Model pengembangan layanan informasi karier berbasis media blog dapat dilihat pada Gambar 1.

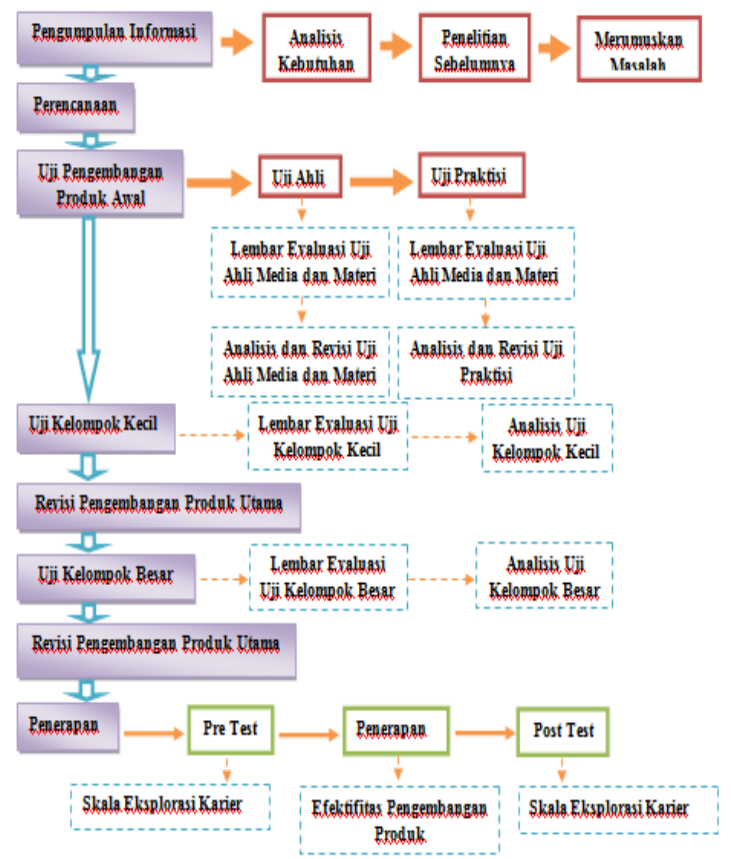

Gambar 1. Model pengembangan layanan informasi karier berbasis media blog dapat dilihat pada

Pengumpulan informasi dilaksanakan melalui analisis kebutuhan, penelitian sebelumnya, dan merumuskan masalah. Analisis kebutuhan denganmengumpulkan informasi melalui wawancara dengan beberapa siswa di SMP Kota Magelang, guru Bimbingan dan Konseling di SMP Kota Magelang, serta guru Bimbingan dan Konseling yang terlibat PPDB di SMA dan SMK Kota Magelang.Penelitian sebelumnya untuk mendukung pengembangan informasi karier berbasis media blog. Terdapat dua rumusan masalah yaitu mengetahui kelayakan layanan informasi karier berbasis media blog dan mengetahui efektifitas layanan informasi karier berbasis media blog untuk meningkatkan eksplorasi karier siswa di SMP Kota Magelang. Rumusan masalah tersebut yang dilakukan peneliti untuk menjawab pertanyaan masalah.

Perencanaan dengan mengumpulkan materi serta merancang dan menentukan desain pengembangan informasi karier berbasis media blog. Pengumpulan materi dilaksanakan pada 21 September 2016 sampai 26 November 2016 pada SMA dan SMK di Kota Magelang. Berdasarkan pengumpulan materi diketahui bahwa terdapat 29 program studi keahlian dan 34 kelanjutan studi di Kota Magelang. 29 program studi keahlian dijadikan dasar dalam pembuatan skala peminatan. Perancangan dan penentuan desain informasi karier berbasis media blog dapat diakses pada sekolahkotamagelang.blogspot.co.id. dapat dilihat pada Gambar 2. Sedangkan skala peminatan dapat dilihat pada Gambar 3. 


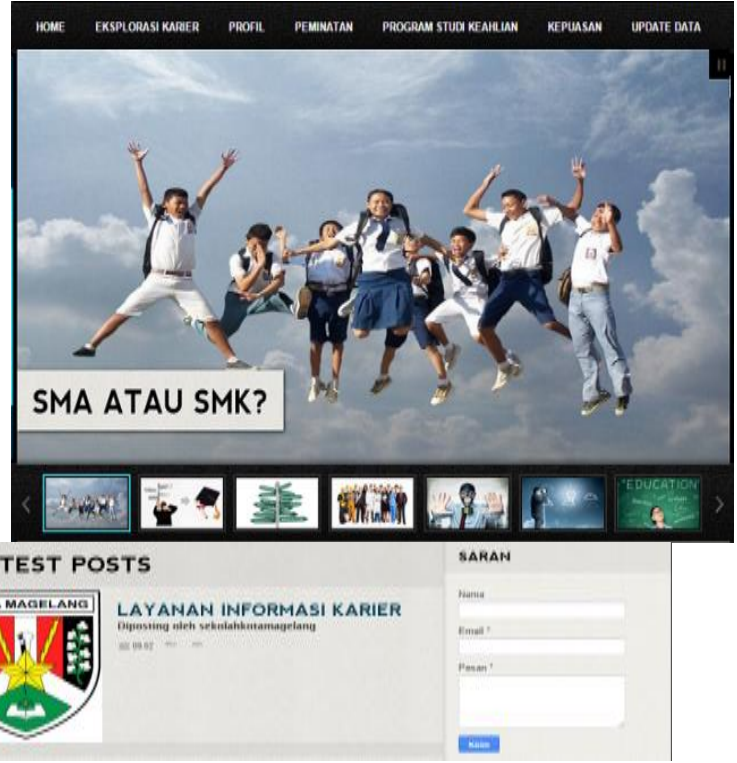

Gambar 2. Desain Informasi Karier Berbasis Media Blog

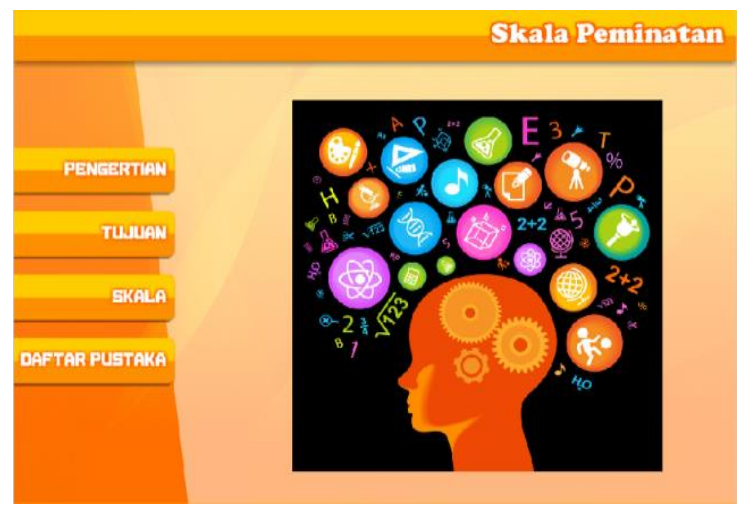

Gambar 3. Desain Skala Peminatan

Uji pengembangan produk awal kepada ahli media dan materi serta praktisi. Hasil uji pengembangan produk awal ahli media diketahui skor 42 dalam kategori Sangat Sesuai/ Sangat Baik/ Sangat Tepat.Ahli materi dengan skor 30 dalam kategori Sesuai/ Baik/ Tepat. Berdasarkan data kuantitatif menggunakan lembar evaluasi dari uji ahli media dan materi maka dapat dilanjutkan uji praktisi.

Uji praktisi di SMP Negeri 8 Magelang diketahui skor 36 dalam kategori Sangat Sesuai/ Sangat Baik/ Sangat Tepat.Uji praktisi di SMP Muhammadiyah Magelang dengan skor 32 dalam kategori Sesuai/ Baik/ Tepat. Berdasarkan data kuantitatif menggunakan lembar evaluasi dari uji praktisi maka dapat dilanjutkan uji kelompok kecil.

Uji kelompok kecil kepada 3 siswa kelas VIII F di SMP Negeri 8 Magelang diketahui rata-rata skor 29 dalam kategori Sesuai/ Baik/ Tepat. Uji kelompok kecil pada 3 siswa kelas VIII B di SMP Muhammadiyah Magelang dengan rata-rata skor 34 dalam kategori Sangat Sesuai/ Sangat Baik/ Sangat Tepat. Berdasarkan data kuantitatif menggunakan lembar evaluasi dari uji kelompok kecil maka dapat dilanjutkan uji kelompok besar.
Uji kelompok besar kepada 18 siswa di kelas VIII F di SMP Negeri 8 Magelangdiketahui 18 siswa di SMP Negeri 8 Magelang dengan rata-rata skor 31 dalam kategori Sesuai/ Baik/ Tepat. Uji kelompok besar pada 12 siswa di SMP Muhammadiyah Magelang dengan rata-rata skor 33 dalam kategori Sangat Sesuai/ Sangat Baik/ Sangat Tepat. Berdasarkan data kuantitatif menggunakan lembar evaluasi dari uji kelompok besar maka dapat dilanjutkan uji efektifitas produk.

Selain data kuantitatif tersebut juga terdapat data kualitatif pada lembar evaluasi uji ahli media dan materi, uji praktisi, uji kelompok kecil, dan uji kelompok besar. Data kualitatif berupa masukan atau saran setelah menguji layanan informasi karier berbasis media blog. Data kualitatif dianalisis dan direvisi untuk menyempurnakan informasi karier berbasis media blog sebelum diberikan kepada siswa di SMP Kota Magelang sebagai layanan untuk membantu meningkatkan eksplorasi karier dalam menentukan program studi keahlian, menentukan kelanjutan studi, dan mengembangkan rencana pekerjaan sementara yang akan dijabat siswa setelah menyelesaikan pendidikan tingkat SMP.

Penerapan dilakukan tiga tahapan, yaitu pre test, uji efektifitas, dan post test. Pre test menggunakan skala eksplorasi karier untuk mengetahui tingkat eksplorasi karier awal siswa. Uji efektifitas dengan eksperimen pengembangan produk. Post test menggunakan skala eksplorasi karier untuk mengetahui efektifitas pengembangan produk. Penerapan dilakukan uji normalitas dan uji t menggunakan SPSS.

Pada penerapan ditentukan hipotesis bahwa HO = Tidak terdapat perbedaan signifikan sebelum dan setelah diberikan layanan informasi karier berbasis media blog dan $\mathrm{H} 1=$ terdapat perbedaan signifikan sebelum dan setelah diberikan layanan informasi karier berbasis media blog, menentukan $t$ tabel, menentukan signifikansi, dan pengambilan keputusan dengan ketentuan taraf signifikansi > 0.05 dengan t hitung < maka H0 diterima (H1 ditolak) dan taraf signifikansi $\leq 0.05$ dengan $\mathrm{t}$ hitung $>\mathrm{t}$ tabel maka $\mathrm{H} 0$ ditolak ( $\mathrm{H} 1$ diterima).

Hasil pre test tingkat eksplorasi karier pada 28 siswa kelas VIII G di SMP Negeri 8 Magelang dengan rata-rata skor 131 dalam kategori sedang, setelah diberikan layanan informasi karier berbasis media blog dan post test dengan rata-rata skor 140 dalam kategori tinggi. Hasil pre test tingkat eksplorasi karier pada 21 siswa kelas VIII A di SMP Muhammadiyah Magelang dengan rata-rata skor 128 dalam kategori sedang, setelah diberikan layanan informasi karier berbasis media blog dan post test dengan rata-rata skor 144 dalam kategori tinggi.

Data pre test dan post test pada uji efektifitas diolah menggunakan SPSS untuk dilakukan uji normalitas untuk mengetahui data tersebut berdistribusi normal atau tidak. Pengolahan data menggunakan Shapiro-Wilk, hal tersebut dikarenakan jumlah sampel kurang dari 50. Hasil uji normalitas pre test menunjukkan 0.297 dan post test menunjukkan 0.361. Berdasarkan hasil uji normalitas diketahui nilai probabilitas pre test dan post test lebih besar 
dari taraf signifikan $5 \%$ (pre test $0.297>0.05$ dan post test $0.361>0.05)$, maka data dikatakan berdistribusi normal dan dapat dilakukan uji t.

Setelah diketahui data berdistribusi normal maka dilakukan uji $\mathrm{t}$ untuk mengetahui efektifitas layanan informasi karier berbasis media blog. Hasil uji t diketahui taraf signifikan pre test dan post test lebih kecil dari taraf signifikan $5 \%(0.000 \leq 0.05)$. Layanan informasi karier berbasis media blog dinyatakan layak untuk meningkatkan eksplorasi karier siswa SMP di Kota Magelang.

Siswa membutuhkan layanan informasi karier untuk membantu mengeksplorasi kariernya. Parwoko [15] menyatakan layanan informasi bertujuan supaya siswa dapat mengorientasikan dirinya kepada informasi yang diperoleh terutama kehidupannya saat masih sekolah atau setelah lulus sekolah, siswa mengetahui sumber informasi yang diperlukan, siswa dapat menggunakan kegiatan kelompok sebagai sarana memperoleh informasi, serta siswa dapat memilih dengan tepat kesempatan yang ada di lingkungan sesuai minat dan kemampuan.Informasi karier dibutuhkan siswa SMP di Kota Magelang untuk membantu menentukan program studi keahlian dan kelanjutan studi di SMA dan SMK Kota Magelang.

Oddo (dalam [16]), layanan informasi bertujuan membantu merencanakan kehidupan karier siswapada bidang pendidikan, kejuruan, dan pribadi sosial. Sedangkan Iwuama (dalam [17]), informasi karir bertujuan membantu memahami diri siswa dalam memilih dan mengelola karir secara tepat sehingga dapat memiliki pengembangan karir yang baik dan dunia kerja. Pendapat tersebut sesuai dengan tujuan pemberian layanan informasi karier berbasis media blog yaitu meningkatkan eksplorasi karier siswa dalam menentukan program studi keahlian, kelanjutan studi, dan mengembangkan rencana pekerjaan sementara yang akan dijabatnya.

Materi layanan informasi karier berbasis media blog yang dikembangkan memberikan informasi mengenai program studi keahlian, kelanjutan studi, dan peluang kerja lulusan supaya siswa memahami eksplorasi kariernya. Ocansey, Forde, Awabil, \& Otopa (dalam [16]) menyatakan materi layanan informasi meliputi informasi perguruan tinggi serta kelanjutan studi ke SMA dan SMK. Materi layanan informasi karier berbasis media blog memberikan informasi tentang kelanjutan studi ke SMA dan SMK.

Layanan informasi karier dapat disampaikan melalui berbagai media, salah satu media yang digunakan peneliti yaitu website jenis blog. Liu [18], blog (weblog) merupakan jurnal online atau diari dan berita terbaru yang diperbaharui secara teratur, secara kronologis. Blog menjadikan pembuat dan pengunjung lebih interaktif. Blog memungkinkan pengunjung untuk menuliskan komentar, menanggapi, atau mengajukan pertanyaan terkait informasi yang sudah dipublikasi.

Peneliti mengembangkan informasi karier yang pada awalnya disampaikan menggunakan media brosur menjadi media blog. Hewitt (dalam [11]), blog merupakan revolusi informasi media cetak dalam penyebaran informasi.
Informasi karier yang diberikan Guru Bimbingan dan Konseling menggunakan media brosur belum dapat memberikan pemahaman eksplorasi, melalui informasi karier berbasis media blog diharapkan dapat meningkatkan pemahaman eksplorasi kariersiswa di SMP Kota Magelang.

Stock [19], terdapat sembilan jenis blog. Sembilan jenis blog tersebut yaitu blog politik, blog teknologi, blog keluarga, blog olahraga, quilting blogs, housewife blogs, blog sekolah, blog guru, dan blog sindiran. Blog yang digunakan peneliti untuk memberikan informasi karier termasuk dalam blog sekolah.

Banyak manfaat dari penggunaan media blog. Salah satu manfaat blog yaitu untuk pembelajaran terkait eksplorasi dijelaskan Park, Heo, \& Lee [20]. Blog untuk pembelajaran bermanfaat supaya guru dapat secara aktif memimpin kegiatan pembelajaran yang efektif dan mengarahkan dirinya menjadi seorang pengelola blog, serta untuk menanamkan pembelajaran yang efektif dalam hal eksplorasi.

Pemberian layanan informasi karier berbasis media blog diharapkan dapat meningkatkan eksplorasi karier siswa dalam menentukan program studi keahlian, kelanjutan studi, dan mengembangkan rencana pekerjaan sementara sesuai minat, bakat, dan kemampuan akademik atau kejuruan. Informasi karier berbasis media blog menyediakan skala peminatan untuk membantu siswa memahami minat, bakat, dan kemampuan akademik atau kejuruan sebelum menentukan program studi keahlian dan kelanjutan studi serta mengembangkan rencana pekerjaan sementara.

Pengertian peminatan dijelaskan dalam Peraturan Menteri Pendidikan dan Kebudayaan Republik Indonesia [12] tentang Bimbingan dan Konseling pada Pendidikan Dasar dan Pendidikan Menengah sedangkan tujuan peminatan dijelaskan dalam Peraturan Menteri Pendidikan dan Kebudayaan Republik Indonesia [13] tentang Peminatan pada Pendidikan Menengah. Pengertian dan tujuan peminatan dalam Peraturan Menteri Pendidikan dan Kebudayaan Republik Indonesia menjadi dasar hokum untuk membuat skala peminatan.

Skala peminatan dibuat menggunakan program Adobe Flash. Andi [21], dan Chandra [22] menyatakan Adobe Flash merupakan salah satu software yang salah satunya dapat digunakan untuk mengerjakan hal terkait website atau web interaktif. Skala peminatan menggunakan Adobe Flash dapat mendukung informasi karier berbasis media blog.

Banyak ahli yang mendefinisikan tentang eksplorasi karier. Flum \& Blustein [23], eksplorasi karier merupakan proses yang melibatkan fungsi kehidupan kritis dan penyesuaian diri. Super (dalam [24]), eksplorasi karier merupakan dimana siswa mengeksplorasi lingkungan tempat tinggal, perkembangan sub kebudayaan, peran diri, dan kesempatan untuk bemain peran sesuai kepribadian, minat, dan bakat. Penelitian Purwanta [1], menyatakan bahwa eksplorasi karier adalah upaya mencari dan menguji karakter diri yang berkaitan dengan kelemahan dan kekuatan, serta menguji informasi tentang lingkungan karier berkaitan dengan kesempatandan ancaman dalam mencapai tujuan karier. 
Faktor eksplorasi karier dijelaskan Heppner, Kreishock, Ellis, Taylor (dalam [23]), faktor nilai diri tentang pemecahan masalah, harga diri, dan orientasi terhadap motivasi mempengaruhi eksplorasi karier. Blustein (Reed, 1999,p.14), Faktor yang mempengaruhi eksplorasi karier yaitu faktor orang terdekat dan diri. Faktor orang terdekat yaitu keluarga. Faktor diri yaitu perbedaan kepribadian, harga diri, kemampuan siswa dalam memecahkan masalah, dan lainnya. Penelitian Purwanta [1] bahwa terdapat dua faktor yang mempengaruhi eksplorasi karier pada siswa SMP yaitu faktor diri terkait kepribadian dan faktor orang tua terkait aspirasi. Menurut Mortimer (dalam [25]), faktor yang mempengaruhi eksplorasi karier yaitu keluarga, lingkungan, dan diri. Faktor yang mempengaruhi eksplorasi karier yaitu faktor diri meliputi perbedaan kepribadian, harga diri, motivasi, kemampuan memecahkan masalah; faktor keluarga meliputi orang terdekat dan aspirasi orang tua; serta faktor lingkungan.

Terdapat dua aspek penting dalam eksplorasi karier. Blustein [23], Greenhaus \& Callanan [26] yaitu aspek diri dan aspek lingkungan. Eksplorasi diri mendefinisikan tentang minat, bakat, nilai, pengalaman, dan tujuan karier.Eksplorasi lingkungan tersebut meliputi jabatan, pekerjaan, organisasi, dan keluarga.

\section{KESIMPULAN DAN SARAN}

\section{A. Kesimpulan}

Informasi karier berbasis media blog layak menjadi layanan untuk digunakan siswa di SMP Kota Magelang.Layanan informasi karier berbasis media blog layak untuk meningkatkan eksplorasi karier siswa SMP di Kota Magelang. Berdasarkan hasil uji normalitas pre test dan post test, nilai probabilitas pre test dan post test lebih besar dari taraf signifikan $5 \%$ (pre test $0.297>0.05$ dan post test $0.361>0.05$ ) maka data dikatakan berdistribusi normal, sedangkan hasil uji t diketahui taraf signifikan pre test dan post test lebih kecil dari taraf signifikan $5 \%(0.000 \leq 0.05)$.

\section{B. Saran}

Penelitian ini menyarankan kepada siswa yang kurang yakin setelah diberikan layanan informasi karier berbasis media blog karena skor skala peminatan atau program studi keahlian dan kelanjutan studi di Kota Magelang dapat berkonsultasi dengan orang tua atau guru Bimbingan dan Konseling sebelum menentukan program studi keahlian dan kelanjutan studi mendatang. Kepada guru Bimbingan dan Konseling di SMP Kota Magelang supaya dapat memberikan layanan informasi karier berbasis media blog kepada siswa kelas lain dan dapat mengembangkan media lain untuk membantu mengatasi masalah eksplorasi karier siswanya. Kepada peneliti selanjutnya diharapkan dapat mengembangkan layanan informasi karier berbasis media blog sampai tahap desimilasi dan implementasi produk.

\section{DAFTAR PUSTAKA}

[1] Purwanta, E. (2012). Faktor yang mempengaruhi eksplorasi karier siswa SLTP, Cakrawala Pendidikan, 2, 228-243.

[2] Ting, S. R., Leung, Y. F., Stewart, K., et al. (2012). A preliminary study of career education in middle school. Journal of Career and Technical Education, 27 (2), 84-97.

[3] O'Donogue, K. (2014). Career guidance in school and collages: A guide to best practice and commissioning careers guidance services. UK: Career Development Institute.

[4] Prayitno dan Amti, E. (2008). Dasar-dasar bimbingan dan konseling. Jakarta: Rineka Cipta.

[5] Anwar, M. K. (2016). Pengembangan buku kerja eksplorasi karier pada siswa sekolah menengah pertama ali maksum Bantul Daerah Istimewa Yogyakarta. Skalais magister, tidak diterbitkan, Universitas Negeri Yogyakarta, Yogyakarta.

[6] Moly, T. M. (2007). Career guidance through libraries in higher educational institution. Annals of Library and Information Studies, 54, 185-189.

[7] Sweet, R. (2001). Career information, guidance and counseling services: Police perspectives. Australian Journal of Career Development, 10 (2), 1-11.

[8] The Scottish Government. (2011). Career information, advice and guidance in Scotland: A framework for services redesign and improvement, March 2011. Edinburg: The Scottish Government.

[9] Daniel, A. J. H. (2001). An exploration of middle and high school students' perceptions of deviant behavior when using computers and the internet. Disertasi doktor, tidak diterbitkan, The Louisiana State University, Louisiana.

[10] Miller, G. E. (2002). The effect of an internet based career exploration strategy on the abilities of students with emotional disturbance to find, organize, and communicate Information about career interest. Disertasi doktor, tidak diterbitkan, Johns Hopkins University, Maryland.

[11] Shim, J. P., \& Guo, C. (2009). Weblog technology for instruction, learning, and information delivery. Decision Sciences Journal of Innovative Education, 7 (1), 171-193.

[12] Permendikbud. (2014). Peraturan Pemerintah RI Nomor 111, Tahun 2014, tentang Bimbingan dan Konseling pada Pendidikan Dasar dan Pendidikan Menengah.

[13] Permendikbud. (2014). Peraturan Pemerintah RI Nomor 64 Pasal 2, Tahun 2014, tentang Peminatan pada Pendidikan Menengah

[14] Borg, W. R., \& Gall, M. D. (1983). Education research an introduction. New York: Logman.

[15] Parwoko, B. (2008). Organisasi dan manajemen bimbingan dan konseling. Surabaya: Unesa University Press.

[16] Sedofia, J. (2014). Informing the less informed: The information services of the school guidance programme. International Journal for Innovation Education and Research, 2 (4), 57-61.

[17] Omeje, J. C., Eze, J. U., \& Egeonu, D. C., (April-June 2016). Utilization of E-counseling in career information dissemination among undergraduaskala of Federal Universities in South East Nigeria. Sage Open, 2, 1-8.

[18] Liu, L. (2008). Information content of blogs with firm specific news. Disertasi doktor, tidak diterbitkan, The University of Texas at Dallas, Dallas.

[19] Stock, M. J. (2009). The school administrator's guide to blogging: A new way to connect with the community. United State of America: Rowman \& Littlefield Publishers, Inc.

[20] Park, Y., Heo, G. M., \& Lee, R. (2011). Blogging for informal learning: Analyzing bloggers' using learning perspective. Educational Technology \& Society, 14 (2), 149-160.

[21] Andi, P. (2005). Presentasi multimedia dengan macromedia flash. Yogyakarta: Andi.

[22] Chandra. (2007). Flash CS3 untuk orang awam. Palembang: Maxikom.

[23] Blustein, D. L. (1997). A context rich perspective of career exploration across the life roles. The Career Development Quarterly, 45 (3), 260-274 
[24] Faulkner, P. E., Steward, A., \& Baggett, C. (2006). Middle school career exploration. The agricultural education magazine, 78 (5), 2224.

[25] Hellmann, J. E. (2014). Social and psychological factors related to the career exploration process of young adults. Skalais magister, tidak diterbitkan, University of Kentucky, Kentucky.

[26] Greenhaus, J. H., \& Callanan, G. A. (2006). Encyclopedia of career development. Thousand Oaks. California: Sage Publication, Inc. 